INTERNATIONAL JOURNAL OF MULTIDISCIPLINARY RESEARCH AND ANALYSis

ISSN(print): 2643-9840, ISSN(online): 2643-9875

Volume 04 Issue 03 March 2021

DOI: 10.47191/ijmra/v4-i3-08, Impact Factor: 6.072

Page No.- 268-274

\title{
The Effect of Work Discipline and Work Motivation on the Performance of Medical Personnel
}

\author{
Rumiris Siahaan ${ }^{1}$, Suci Etri Jayanti ${ }^{2}$ \\ ${ }^{1,2}$ Binakarya College of Economics
}

\begin{abstract}
The results of this study indicate. (1) It can be seen that the amount of the adjusted R square value is 0.632 or $63.2 \%$. This shows that the Work Discipline Variable (X1) and the Work Motivation Variable (X2) can explain the Medical Personnel Performance Variable $(\mathrm{Y})$ of $63.2 \%$, the remaining $36.8 \%(100 \%-63.2 \%)$ is explained by other variables outside this research model. (2) The results of the $t$ test (partial) show that $t$ count $(8,211)>t$ table $(1.685)$, as well as the significance value of 0.00 $<0.05$, it can be concluded that the first hypothesis is accepted, meaning that the variable of work discipline (X1) has a significant effect on the Medical Personnel Performance Variable (Y). (3) The results of the $t$ test (partial) can be seen that tcount $(-1.298)>t$ table (1.685), and the significance value is $0.202>0.05$, it can be concluded that the second hypothesis is rejected, meaning that the Work Motivation Variable (X2) has no significant effect on Medical Personnel Performance Variable (Y). (4) The results of the simultaneous test (F) show that the Ftable value is 3.22. From the description, it can be seen that Fcount (34.461)> Ftable (3.25), and a significance value of $0.00<0.05$, it can be concluded The third hypothesis is accepted, meaning that the Work Discipline Variable (X1), Work Motivation Variable (X2) have a significant effect simultaneously (simultaneously) on the Performance Variable of Medical Personnel (Y).
\end{abstract}

KEYWORDS: Work Discipline, Work Motivation and Performance of Medical Personnel

\section{INTRODUCTION}

Human Resources are essentially one of the important assets in order to run a good operation in accordance with the objectives of the company. Therefore, companies need to manage Human Resources as best as possible. In companies engaged in the health sector such as hospitals, the required human resources must have really good quality in order to serve patients well. Human Resources is a crucial aspect to support the productivity of a hospital so that it can survive in today's intense competition.

Definition of Medical Personnel In Law Number 36 Year 2014, what is meant by health workers is anyone who devotes himself to the health sector and has knowledge and / or skills through education in certain types of health that require the authority to make health efforts. In the book Health Service Quality Assurance and Acceptability (Bustami, 2011), Anireon's opinion states that medical personnel are medical experts whose main function is to provide medical services to patients with the best quality by using procedures and techniques based on medical science and ethics. valid and can be accounted for. Medical personnel have several important tasks to serve the community, the first is promotional services, namely health promotion where medical personnel help people so that their lifestyle becomes optimally healthy, but in reality, health promotion is rarely carried out seen from the lifestyle and the community's living environment that has not shown public concern about the importance of health. The second is preventive health services in the form of preventive activities against a health problem / disease but in reality, prevention is even carried out after a health problem has first caused a victim. The third is curative health services, which are medical activities to reduce pain and also in the form of efforts to cure illnesses so that sufferers feel better, but in reality patients who come for treatment are not immediately served because of incomplete administration or because they do not have money. Next is the role of medical personnel to provide rehabilitative health services. Therefore, the company must be able to manage employees well so that employee performance can be maximized, there are no conflicts between employees, and employee job satisfaction is achieved. 


\section{The Effect of Work Discipline and Work Motivation on the Performance of Medical Personnel}

\section{FORMULATION OF THE PROBLEM}

Based on the background of the research, in order to facilitate the analysis, the writer formulates the following problems:

1. Does work discipline affect the performance of medical personnel at Sri Pamela Hospital, Tebing Tinggi City?

2. Does work motivation affect the performance of medical personnel at Sri Pamela Hospital, Tebing Tinggi City?

3. Do work discipline and work motivation simultaneously influence the performance of medical personnel at Sri Pamela Hospital, Tebing Tinggi City?

\section{THEORETICAL BASIS}

\section{A. Definition of Employee Performance}

The definition of performance is the work result in quality and quantity achieved by an employee in carrying out his duties in accordance with the responsibilities assigned to him Mangkunegara (2013: 01). Performance according to Fahmi (2014: 01) is the result obtained by an organization, whether the organization is profit oriented and non-profit oriented which is generated over a period of time. A corporate organization was founded because it has certain goals it wants and must achieve. In achieving its goals, every organization is influenced by organizational behavior. One of the activities most commonly carried out in organizations is employee performance, namely how he does everything related to a job or role in the organization. The definition of performance or performance is a description of the level of achievement of the implementation of an activity program or policy in realizing the goals, objectives, vision and mission of the organization as outlined in the strategic planning of an organization.

According to Widodo (2015) Performance is the level of achievement of results for the implementation of certain tasks. Simanjuntak also defines individual performance as the level of achievement or a person's work results from targets that must be carried out within a certain period of time. From some of the above meanings, the basis used in this research is Mangkunegara's opinion which states that employee performance is the quality and quantity of work achieved by an employee in carrying out his duties in accordance with the responsibilities assigned to him. So it can be concluded that the definition of the work performance of employees both quality and quantity achieved by employees in a certain period is in accordance with the given responsibilities.

\section{B. Definition of Work Discipline}

To achieve organizational goals, harmonious teamwork is required and high awareness for each member of the organization to work together seriously and comply with the agreed regulations. In general, someone's discipline can be seen from the person's behavior in carrying out their duties. In more depth, discipline includes dimensions of attitude that involve a person's mental. There are several definitions of discipline put forward by experts, including: According to Rivai (2011: 825) that: "Work discipline is a tool used by managers to communicate with employees so that they are willing to change a behavior and as an effort to increase awareness. and one's willingness to comply with all company regulations. Discipline will allow a person to distinguish what should be done, what must be done, what can be done and what should not be done (because things are prohibited).

\section{Definition of Work Motivation}

Hamzah B. Uno (2012: 71) which states; "Work motivation is one of the factors that determine a person's performance, the size of the influence of work motivation on one's performance depends on how much motivation intensity is given." Another potential that is no less important is employee motivation. Meanwhile, this motivation is the driving force that causes an organization member to be willing and willing to take the time to carry out various activities to become his responsibility and to fulfill his obligations in terms of achieving the goals and objectives of the organization that are determined in advance.

\section{RESEARCH METHOD}

\section{A. Research sites}

This research will be conducted at Sri Pamela Hospital, Tebing Tinggi City, which is located at Jalan Jenderal Sudirman Sri Padang Kec. Tebing Tinggi, North Sumatra

\section{B. Research time}

This research will be conducted in June 2020 .

\section{Type of data}

The type of data used in this study is quantitative data, namely data in the form of numbers. 


\section{The Effect of Work Discipline and Work Motivation on the Performance of Medical Personnel}

\section{Data source}

Primary data is data obtained from direct interviews with employees at the company about history, organizational structure, other information about what activities are carried out.

\section{DISCUSSION}

\section{A. Instrument Test}

\section{Validity Test}

Validity testing uses SPSS version 23 for windows with criteria based on the calculated $r$ value as follows:

a) If $r$ count $>r$ table or $-r$ count $<-r$ table then the statement is declared valid.

b) If $r$ count $<r$ table or $-r$ count $>-r$ table then the statement is declared invalid.

This test was carried out on 40 respondents, then $d f=40-2=38$, with $\alpha=5 \%$, then the $r$ table value was 0.312 (Ghozali, 2016),

\section{Reliability Test}

Reliability is an index that shows the extent to which a measuring device can be trusted or reliable. According to Sugiyono (2013), a factor is declared reliable / reliable if the Cronbach Alpha is greater than 0.6. Based on the results of data processing using SPSS 23 for windows, the following results were obtained:

Table 1. Reliability Test Results :

\begin{tabular}{|l|l|l|l|}
\hline Variabel & Cronbach Alpha & Konstanta & Reliabilitas \\
\hline Variabel X1 & 0,764 & 0,6 & Reliabel \\
\hline Variabel X2 & 0,782 & 0,6 & Reliabel \\
\hline Variabel Y & 0,829 & 0,6 & Reliabel \\
\hline
\end{tabular}

Source: Data processed from attachment 3 (2018)

Based on the reliability test using Cronbach Alpha, all research variables are reliable because the Cronbach Alpha is greater than 0.6 , the results of this study indicate that the measurement tool in this study has met the reliability test (reliable and can be used as a measuring tool).

\section{B. Classic assumption test}

The testing of classical assumptions with the SPSS 23 for windows program carried out in this study includes:

\section{Normality Test}

Normality test aims to test whether in the regression model, confounding or residual variables have a normal distribution (Ghozali, 2016). Data normality testing can be done using two methods, graphs and statistics. The normality test of the graph method uses a normal probability plot, while the normality test of the statistical method uses the one sample Kolmogorov Smirnov Test. The test results using SPSS 23 for windows are as follows:

Table 2. One Sample Kolmogorov Smirnov Test :

One-Sample Kolmogorov-Smirnov Test

\begin{tabular}{|c|c|c|c|}
\hline & & & $\begin{array}{l}\text { Unstandardized } \\
\text { Residual }\end{array}$ \\
\hline$N$ & & & 40 \\
\hline \multirow[t]{2}{*}{ Normal Parameters ${ }^{a, b}$} & Mean & & 0000000 \\
\hline & Std. Deviation & & 1,16209121 \\
\hline \multirow[t]{3}{*}{ Most Extreme Differences } & Absolute & & 102 \\
\hline & Positive & & ,089 \\
\hline & Negative & &,- 102 \\
\hline Test Statistic & & & 102 \\
\hline Asymp. Sig. (2-tailed) & & &, $200^{c, d}$ \\
\hline \multirow[t]{3}{*}{ Monte Carlo Sig. (2-tailed) } & Sig. & &, $700^{e}$ \\
\hline & \multirow[t]{2}{*}{ 99\% Confidence Interval } & Lower Bound & ,513 \\
\hline & & Upper Bound & ,887 \\
\hline
\end{tabular}

\footnotetext{
a. Test distribution is Normal.

b. Calculated from data.
} 


\section{The Effect of Work Discipline and Work Motivation on the Performance of Medical Personnel}

c. Lilliefors Significance Correction.

d. This is a lower bound of the true significance.

e. Based on 40 sampled tables with starting seed 2000000.

From the output in table 2. It can be seen that the significance value (Monte Carlo Sig. Lower Bound) of all variables is 0.513 . If the significance is more than 0.05 , then the residual value is normal, so it can be concluded that all variables are normally distributed.

\section{Multicollinearity Test}

The multicollinearity test aims to determine whether in the regression model there is a correlation between the independent variables. The multicollinearity test in this study is seen from the tolerance or variance inflation factor (VIF) value. The calculation of tolerance or VIF values using the SPSS 23 for windows program can be seen in Table 3 below:

Table 3. Multicollinearity Test Results :

\section{Coefficients $^{a}$}

\begin{tabular}{|c|c|c|c|c|c|c|c|c|}
\hline & & \multicolumn{2}{|c|}{$\begin{array}{l}\text { Unstandardized } \\
\text { Coefficients }\end{array}$} & \multirow{2}{*}{$\begin{array}{l}\text { Standardized } \\
\text { Coefficients } \\
\text { Beta }\end{array}$} & \multirow[b]{2}{*}{$t$} & \multirow[b]{2}{*}{ Sig. } & \multicolumn{2}{|c|}{ Collinearity Statistics } \\
\hline \multicolumn{2}{|c|}{ Model } & B & Std. Error & & & & Tolerance & VIF \\
\hline \multirow[t]{3}{*}{1} & (Constant) & ,272 & 1,769 & & 154 & 879 & & \\
\hline & Disiplin_Kerja_X1 & ,830 & 101 & ,836 & 8,211 & ,000 & ,910 & 1,099 \\
\hline & Movasi_Kerja_X2 &,- 112 & ,086 &,- 132 & $-1,298$ & 202 & 910 & 1,099 \\
\hline
\end{tabular}

a. Dependent Variable: Kierja_Tenaga_Medis_Y

Based on table 3 it can be seen that the tolerance value of the Work Discipline Variable (X1) is 0.910. Work Motivation Variable (X2) is 0.910 , where everything is greater than 0.10 while the VIF value of the Work Discipline Variable (X1) is 1.099 , Motivation Variables Work (X2) is 1.099, where all of them are less than 10. Based on the results of the above calculation, it can be seen that the tolerance value for all independent variables is greater than 0.10 and the VIF value of all independent variables is also less than 10 so that there is no correlation symptom on the independent variable. So it can be concluded that there are no symptoms of multicollinearity between independent variables in the regression model.

\section{Heteroscedasticity Test}

The heteroscedasticity test aims to test whether from the regression model there is an inequality of variance from one residual observation to another. A good regression model is one that is homoscedastic or does not occur heteroscedasticity. One way to detect the presence or absence of heteroscedasticity is the Scatterplot.

Multiple Linear Regression Testing

Multiple linear regression testing explains the role of the Work Discipline Variable (X1), Work Motivation Variable (X2) on the Performance Variable of Medical Personnel (Y). The data analysis in this study used multiple linear regression analysis using SPSS 23 for windows. The analysis of each variable is described in the following description:

Table 4. Multiple Linear Regression Results :

\section{Coefficients $^{\mathrm{a}}$}

\begin{tabular}{|c|c|c|c|c|c|c|c|c|}
\hline & & \multicolumn{2}{|c|}{$\begin{array}{l}\text { Unstandardized } \\
\text { Coefficients }\end{array}$} & \multirow{2}{*}{$\begin{array}{l}\text { Standardized } \\
\text { Coefficients } \\
\text { Beta }\end{array}$} & \multirow[b]{2}{*}{$\mathrm{t}$} & \multirow[b]{2}{*}{ Sig. } & \multicolumn{2}{|c|}{ Collinearity Statistics } \\
\hline \multicolumn{2}{|c|}{ Model } & B & Std. Error & & & & Tolerance & VIF \\
\hline \multirow[t]{3}{*}{1} & (Constant) & 272 & 1,769 & & 154 & 879 & & \\
\hline & Disiplin_Kerja_X1 & ,830 & 101 & ,836 & 8,211 & ,000 & ,910 & 1,099 \\
\hline & Movasi_Kerja_X2 &,- 112 & ,086 &,- 132 & $-1,298$ & 202 & 910 & 1,099 \\
\hline
\end{tabular}

a. Dependent Variable: Kierja_Tenaga_Medis_Y

Based on these results, the multiple linear regression equation has the formulation: $Y=a+b 1 X 1+b 2 X 2+\varepsilon$, so that the equation is: $Y=0.272+0.830 \times 1-0.112 \times 2$ 


\section{The Effect of Work Discipline and Work Motivation on the Performance of Medical Personnel}

The description of the multiple linear regression equation above is as follows :

a. The constant value (a) of 0.272 shows the magnitude of the Medical Personnel Performance Variable ( $\mathrm{Y}$ ) if the Work Discipline Variable (X1), the Work Motivation variable (X2) is equal to zero.

b. The regression coefficient value of Work Discipline Variable (X1) (b1) of (0.830) indicates the magnitude of the role of the Work Discipline Variable (X1) on the Performance Variable of Medical Personnel (Y) assuming that the Work Motivation Variable (X2) is constant. This means that if the Work Discipline Variable (X1) factor increases by 1 unit of value, it is predicted that the Medical Personnel Performance Variable $(\mathrm{Y})$ will increase by $(0.820)$ a unit value assuming the Work Motivation Variable (X2) is constant.

c. The regression coefficient value of the Work Motivation Variable (X2) (b2) of (-0.112) indicates the magnitude of the role of the Work Motivation Variable (X2) on the Performance Variable of Medical Personnel (Y) assuming that the Work Discipline Variable (X2) is constant. This means that if the Work Motivation Variable (X2) increases by 1 unit of value, it is predicted that the Medical Personnel Performance Variable $(Y)$ will decrease by $(-0.112)$ a unit value assuming that the Work Motivation Variable (X2) is constant.

\section{Coefficient of Determination (R2)}

The coefficient of determination is used to see how much the independent variable contributes to the dependent variable. In other words, the determinant coefficient value is used to measure the magnitude of the contribution of the variable under study $X$ and $Y$ as the dependent variable.

The greater the coefficient of determination, the better the ability of variable $X$ to explain variable $Y$.If determination (R2) is greater (close to 1 ), then it can be said that the influence of variable $X$ is large on variable $Y$.The formula for the coefficient of determination is as follows:

This shows that the model used is getting stronger to explain the effect of variable $X$ on variable $Y$. Conversely, if the determination (R2) is getting smaller (close to zero), it can be said that the effect of variable $X$ on variable $Y$ is getting smaller. This shows that the model used is not strong enough to explain the effect of variable $X$ on variable $Y$.

The value used in looking at the coefficient of determination in this study is in the adjusted $\mathrm{R}$ square column. This is because the adjusted $R$ square value is not susceptible to the addition of independent variables. The coefficient of determination can be seen in Table 5. The following:

Table 5. Coefficient of Determination :

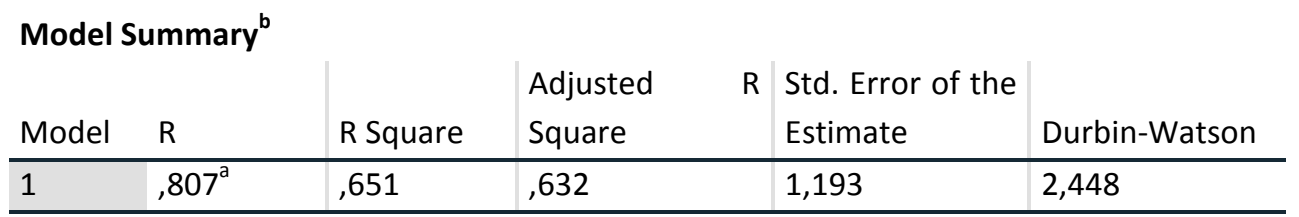

a. Predictors: (Constant), Movasi_Kerja_X2, Disiplin_Kerja_X1

b. Dependent Variable: Kierja_Tenaga_Medis_Y

Based on table 5, it can be seen that the adjusted $\mathrm{R}$ square value is 0.632 or $63.2 \%$. This shows that the Work Discipline Variable (X1) and Work Motivation Variable (X2) can explain the Medical Personnel Performance Variable (Y) by $63.2 \%$, the rest $36.8 \%$ $(100 \%-63.2 \%)$ is explained by other variables outside this research model.

\section{Hypothesis Testing}

1. $t$ test (partial)

The $t$ statistical test is also known as the individual significance test. This test shows how far the influence of the independent variable partially on the dependent variable.

In this study, a partial hypothesis test was carried out on each independent variable as in Table 4:11 below:

Table 6. Partial Test (t) :

Coefficients $^{\mathrm{a}}$

\begin{tabular}{|c|c|c|c|c|c|c|c|c|}
\hline & & \multicolumn{2}{|c|}{$\begin{array}{l}\text { Unstandardized } \\
\text { Coefficients }\end{array}$} & \multirow{2}{*}{$\begin{array}{l}\text { Standardized } \\
\text { Coefficients } \\
\text { Beta }\end{array}$} & \multirow[b]{2}{*}{$\mathrm{t}$} & \multirow[b]{2}{*}{ Sig. } & \multicolumn{2}{|c|}{ Collinearity Statistics } \\
\hline \multicolumn{2}{|c|}{ Model } & B & Std. Error & & & & Tolerance & VIF \\
\hline \multirow[t]{3}{*}{1} & (Constant) & ,272 & 1,769 & & ,154 & 879 & & \\
\hline & Disiplin_Kerja_X1 & ,830 & 101 & ,836 & 8,211 & ,000 & 910 & 1,099 \\
\hline & Movasi_Kerja_X2 &,- 112 & ,086 &,- 132 & $-1,298$ & 202 & 910 & 1,099 \\
\hline
\end{tabular}




\section{The Effect of Work Discipline and Work Motivation on the Performance of Medical Personnel}

a. Dependent Variable: Kierja_Tenaga_Medis_Y

a. Hypothesis Testing The Effect of Work Discipline Variables (X1) on the Performance of

\section{E. Medical Personnel (Y)}

The form of hypothesis testing based on statistics and curves can be described as follows:

Decision Making Criteria:

1) Accept $\mathrm{HO}$ if tcount $<$ ttable or -thitung $>$ - ttable or Sig. $>0.05$

2) Reject $\mathrm{HO}$ If tcount $\geq$ ttable or -thitung $\leq$ - ttable or Sig. $<0.05$

From table 4.11, it is obtained that the tcount value is 8,211 With $\alpha=5 \%$, t table $(5 \% ; 40-2=38)$ obtained a t-table value of 1.685. The significance is $0.00<0.05$, it can be concluded that the first hypothesis is accepted, meaning that the Work Discipline Variable (X1) has a significant effect on the Performance Variable of Medical Personnel (Y).

b. Hypothesis Testing The Effect of Work Motivation Variables (X2) on Medical Personnel Performance Variables (Y), the form of hypothesis testing based on statistics and curves can be described as follows:

Decision Making Criteria:

1) Accept, if tcount $>$ ttable or -thitung $>$ - ttable or Sig. $<0.05$

2) Reject, if tcount <ttable or -thitung <- ttabel or Sig. $>0.05$

From table 6 , it is obtained that the tcount value is -1.298 With $\alpha=5 \%$, t table $(5 \% ; 40-2=38)$ obtained a t-table value of 1.685 . The significance is $0.202>0.05$, it can be concluded that the second hypothesis is rejected, meaning that the Work Motivation Variable (X2) has no significant effect on the Medical Personnel Performance Variable (Y).

\section{F Test (Simultaneous)}

This test basically shows whether all the independent variables included in this model have a joint influence on the dependent variable. The results of the $\mathrm{F}$ test can be seen in the following table 7 :

Table 7. Simultaneous Test Results (F)

\section{ANOVA $^{\mathrm{a}}$}

\begin{tabular}{lll|l|l|l|l}
\multicolumn{1}{l}{ Model } & & Sum of Squares & df & Mean Square & F & Sig. \\
\hline \multirow{2}{*}{1} & Regression & 98,107 & 2 & 49,054 & 34,461 &, $000^{b}$ \\
\cline { 2 - 7 } & Residual & 52,668 & 37 & 1,423 & & \\
\cline { 2 - 7 } & Total & 150,775 & 39 & & & \\
\hline
\end{tabular}

a. Dependent Variable: Kierja_Tenaga_Medis_Y

b. Predictors: (Constant), Movasi_Kerja_X2, Disiplin_Kerja_X1

Source: Data processed from attachment 4 (2019)

The form of hypothesis testing based on statistics and curves can be described as follows:

Decision Making Criteria:

a) If the calculated $\mathrm{F}$ value $>\mathrm{F}$ table or Sig. $<0.05$, then $\mathrm{Ha}$ is accepted and $\mathrm{HO}$ is rejected.

b) If the value of $\mathrm{F}$ count $<\mathrm{F}$ table or Sig. $>0.05$ then $\mathrm{Ha}$ is rejected and $\mathrm{HO}$ is accepted.

From the table above, it is obtained that the Fcount value is 34.461 With $\alpha=5 \%$, dk numerator: 3 , dk denominator: $40-2-1$ (5\%; 2; 37) obtained Ftable value of 3.25 From the description it can be seen that Fcount (34.461)> Ftable (3.25), and a significance value of $0.00<0.05$, it can be concluded that the third hypothesis is accepted, meaning that the Work Discipline Variable (X1), Work Motivation Variable (X2) have a significant effect together (simultaneously. ) to the Medical Personnel Performance Variable (Y).

\section{REFERENCES}

1) Anwar Prabu Mangkunegara. 2010. Human Resource Management. PT. Rosdakarya youth. Bandung

2) Augusty, Ferdinand. 2011. Management Research Methods: Research Guidelines for Thesis, Thesis and Management Science Accompanied. Diponegoro University. Semarang

3) Alex S. Nitisemito. 2010. Human Resource Management personnel management. Third Edition. Ghalia Indonesia. Jakarta

4) B. Siswanto Sastrohadiwiryo. 2012. Indonesian Workforce Management. edition 2. PT. Earth Literacy. Jakarta

5) Ghozali, Imam. 2012. Multivariate Analysis Application with SPSS Program, Diponegoro University Publishing Agency, Vol. 100-125. Semarang 
The Effect of Work Discipline and Work Motivation on the Performance of Medical Personnel

6) Hani, T. Handoko. 2014. Personnel and Human Resources Management. BPFE. Yogyakarta.

7) Haryanti. 2015. Health Service Quality Management. Airlangga University. Surabaya

8) Hasibuan, Malayu S. P. 2010, Human Resource Management, Revised Edition: Earth Literacy. Jakarta

9) Prijodarminto, S. 2013. Discipline Tips for Success. PT Pradnya Paramita. Jakarta

10) Purwanto. 2010. Evaluation of learning outcomes. Student Libraries. Yogyakarta

11) Setiawan, F., \& Kartika Dewi, A. 2014. The Effect of Compensation and Work Environment on Employee Performance at CV. Thanks to grace. E-Jurna Management, Udayana University, 3 (5).

12) Samsudin, Sadili. 2010. Human Resource Management. Faithful Library. Bandung

13) Veithzal Rivai. 2014. Human Resource Management for Companies, 6th Edition, PT. Raja Grafindo Persada, Depok, 16956. 